\title{
Acquired haemophagocytic lymphohistiocytosis secondary to multiple myeloma
}

\author{
Ruchi Bhatt, ${ }^{1,2}$ Shaun Xiao, ${ }^{3}$ Pouyan Gohari, ${ }^{2}$ Alida Podrumar ${ }^{1,2}$
}

'Department of Hematology/ Oncology, Nassau University Medical Center, East Meadow, New York, USA

${ }^{2}$ Department of Medicine, Nassau University Medical Center, East Meadow, New York, USA

${ }^{3}$ Nassau University Medical Center, East Meadow, New York, USA

Correspondence to

Dr Ruchi Bhatt, ruchibhatt9@gmail.com

Accepted 23 August 2019
Check for updates

(c) BMJ Publishing Group Limited 2019. No commercial re-use. See rights and permissions. Published by BMJ.

To cite: Bhatt $R$, Xiao $S$, Gohari $\mathrm{P}$, et al. BMJ Case Rep 2019:12:e231084 doi:10.1136/bcr-2019231084

\section{DESCRIPTION}

A 56-year-old man who initially presented with immunoglobulin G lambda solitary sacral plasmacytoma 1 year ago treated with radiation therapy was hospitalised with severe anaemia. Oesophagoduodenoscopy performed 2 months prior had shown non-bleeding gastric mucosal involvement by plasma cell neoplasm. Hospital course was complicated by high fevers and bicytopenia, including transfusion-dependent anaemia. Laboratory data were notable for a markedly elevated

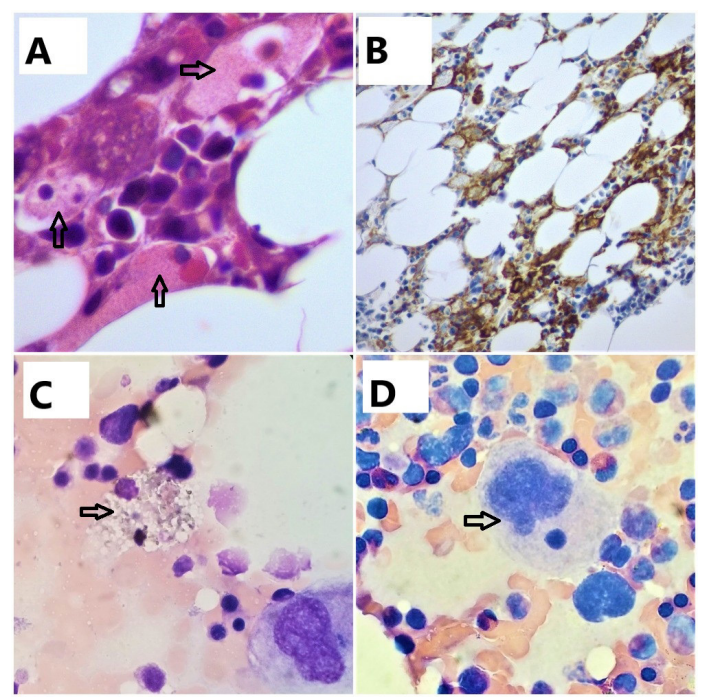

Figure 1 (Panel A) Marked histiocyte hyperplasia with haemophagocytosis. (Panel B) Histiocytes confirmed by positive CD 163 on immunohistochemistry. (Panels $C$ and D) Examples of haemophagocytosis.

Box 1 Diagnostic criteria for acquired haemophagocytic lymphohistiocytosis

- Fever.

- Splenomegaly.

- Cytopenias involving $\geq 2 / 3$ lineages in the peripheral blood: haemoglobin $<9 \mathrm{~g} / \mathrm{dL}$, platelets $<100 \times 10^{9} / \mathrm{L}$, neutrophils $<1.0 \times 10^{9} / \mathrm{L}$.

- Hypertriglyceridaemia and/or hypofibrinogenaemia: fasting triglycerides $\geq 265 \mathrm{mg} / \mathrm{dL}$ and $/$ or fibrinogen $\leq 1.5 \mathrm{~g} / \mathrm{L}$.

- Haemophagocytosisis seen in bone marrow, spleen or lymph nodes.

- Low or absent natural killer cell activity.

- Ferritin $\geq 500 \mu \mathrm{g} / \mathrm{L}$.

- Soluble intreleukin-2 receptor $\geq 2400 \mathrm{pg} / \mathrm{mL}$.

\section{Patient's perspective}

I understand that I have a condition that is very high in mortality but I am trying to undergo treatment for the same. If my case can help other physicians learn, it would mean a lot to me.

\section{Learning points}

- Acquired haemophagocytic lymphohistiocytosis (HLH) especially secondary to multiple myeloma is a very rare diagnosis, but we should definitely think about it in the appropriate clinical setting.

- It is a condition with a very high mortality rate and hence we should maintain a high degree of clinical suspicion to prevent delay in the treatment.

- Etoposide and dexamethasone are the standard of care for HLH.

ferritin level of $16123 \mathrm{U} / \mathrm{mL}$. Bone marrow biopsy findings included marked histiocyte hyperplasia with haemophagocytosis represented by the black arrows in panel A (figure 1, viewed with $100 \times$ objective) and plasma cell involvement of $20 \%$. Panel B (figure 1) shows circumferential brown staining and foamy cytoplasm indicating histiocytes confirmed by positive CD 163 on immunohistochemistry. Further examples of haemophagocytosis are seen in panels $C$ and D (figure 1). The clinical picture of fevers and cytopenias combined with the bone marrow findings and high ferritin established the diagnosis of haemophagocytic lymphohistiocytosis (HLH) which was later confirmed with soluble interleukin-2 receptor level of $10680 \mathrm{pg} / \mathrm{mL}$. He was treated with dexamethasone and etoposide for 8 weeks but eventually succumbed to multiorgan failure. ${ }^{1}$

Acquired HLH can be diagnosed when five out of the following eight criteria are fulfilled as illustrated in box $1 .^{2}$

It can present secondary to an infection, autoimmune disorders or malignancies. It has rarely been described associated with multiple myeloma, especially involving the gastric mucosa making this case unique. It carries a very high mortality rate, and a high index of clinical suspicion is required in order to make the diagnosis and start treatment in a timely manner. 
Acknowledgements The doctors acknowledge Dr Dhaval Desai for putting together the photographs and Dr Sheetal Kumar for assistance with taking photographs.

Contributors RB: clinically took care of the patient and prepared initial write up. SX: helped with initial write up. PG: assisted with clinical management of the patient and pictures. AP: performed final editing of the write up.

Funding The authors have not declared a specific grant for this research from any funding agency in the public, commercial or not-for-profit sectors.

Competing interests None declared.
Patient consent for publication Next of kin consent obtained.

Provenance and peer review Not commissioned; externally peer reviewed.

\section{REFERENCES}

1 Bergsten E, Horne A, Aricó M, et al. Confirmed efficacy of etoposide and dexamethasone in $\mathrm{HLH}$ treatment: long-term results of the cooperative HLH-2004 study. Blood 2017:130:2728-38.

2 Henter Jl, Horne A, Aricó M, et al. HLH-2004: diagnostic and therapeutic guidelines for hemophagocytic lymphohistiocytosis. Pediatr Blood Cancer 2007:48:124-31.

Copyright 2019 BMJ Publishing Group. All rights reserved. For permission to reuse any of this content visit

https://www.bmj.com/company/products-services/rights-and-licensing/permissions/

BMJ Case Report Fellows may re-use this article for personal use and teaching without any further permission.

Become a Fellow of BMJ Case Reports today and you can:

- Submit as many cases as you like

Enjoy fast sympathetic peer review and rapid publication of accepted articles

- Access all the published articles

Re-use any of the published material for personal use and teaching without further permission

Customer Service

If you have any further queries about your subscription, please contact our customer services team on +44 (0) 2071111105 or via email at support@bmj.com.

Visit casereports.bmj.com for more articles like this and to become a Fellow 